\title{
MODEL PEMBELAJARAN ADVANCE ORGANIZER: DAMPAK TERHADAP HASIL BELAJAR KOGNITIF PESERTA DIDIK
}

\section{ADVANCE ORGANIZER LEARNING MODEL: IMPACT AGAINST STUDENT COGNITIVE LEARNING OUTCOMES}

\author{
Levti Norisa Bely ${ }^{1}$, Saiful Bahri ${ }^{2}$, Mukarramah Mustari ${ }^{3}$ \\ ${ }^{1}$ SMP N 1 Batu Ketulis Lampung Barat \\ ${ }^{2}$ Prodi Pendidikan Agama Islam Fakultas Tarbiyah dan Keguruan Universitas Islam Negeri Raden Intan \\ Lampung \\ ${ }^{3}$ Program Pascasarjana Universitas Negeri Semarang \\ E-mail: leftinorisab@gmail.com
}

Diterima: 14 April 2019. Disetujui: 10 Mei 2019. Dipublikasikan: 31 Juli 2019

\begin{abstract}
The purpose of this study is 1) To find out whether there is a significant effect with the Advanced Organizer learning model 2) To improve the cognitive abilities of students on the subject of dynamic fluid Vocational High School. The method used in this study is quasi-experimental with the hypothesis that there is no significant influence on the cognitive abilities of students who are taught using advance organizer learning models so that the cognitive abilities of students are increased. The results of this study indicate that there is a significant influence on the cognitive abilities of students who are taught using an advanced organizer model so that the cognitive abilities of students increase. This can be seen from the results of the pretest and posttest in the experimental class has increased. Significant influence can be proven by the test results from the t-test analysis, where in the t-test analysis the value of $t$-count $>t$-table or significant value $<$ significant level (0.05) is equal to 21,921> 2,045. While the increase in cognitive abilities of experimental class students can be seen from the results of the mean mean value of students at the pretest that is 40.16, an increase after the posttest results of the mean mean becomes 81.94. This means that there is a very good increase in the cognitive abilities of students due to the influence of the Advanced Organizer of Dynamic Fluid SMK models.
\end{abstract}

Keywords: learning model, advanced organizer model, cognitive learning outcomes

Abstrak: Tujuan pada penelitian ini adalah 1) Untuk mengetahui apakah terdapat pengaruh yang signifikan dengan model pembelajaran Advance Organizer 2) Untuk meningkatkan kemampuan kognitif peserta didik pada pokok bahasan fluida dinamis SMK. Metode yang digunakan pada penelitian ini adalah quasi eksperimen dengan hipotesis ada atau tidak pengaruh yang signifikan terhadap kemampuan kognitif peserta didik yang diajar dengan menggunakan model pembelajaran advance organizer sehingga kemampuan kognitif peserta didik lebih meningkat. Hasil dari penelitian ini menunjukkan bahwa terdapat pengaruh yang signifikan terhadap kemampuan kognitif peserta didik yang diajar dengan menggunakan model advance organizer sehingga kemampuan kognitif peserta didik meningkat. Hal ini dapat dilihat dari hasil pretest dan posttest pada kelas eksperimen mengalami peningkatan. Pengaruh signifikan dapat terbukti dengan adanya hasil pengujian dari analisis Uji-t , dimana pada analisis Uji-t nilai $t_{\text {hitung }}>t_{\text {tabel }}$ atau nilai signifikan $<$ taraf signifikan $(0.05)$ yaitu sebesar $21.921>2.045$. Sedangkan peningkatan kemampuan kognitif peserta didik kelas eksperimen dapat dilihat dari hasil rata-rata nilai mean peserta didik pada pretest yaitu 40.16, terjadi peningkatan setelah posttest hasil rata-rata nilai mean menjadi 81.94. Artinya terjadi peningkatan yang sangat baik pada kemampuan kognitif peserta didik akibat pengaruh dari model Advance Organizer pokok bahasan Fluida Dinamis SMK.

(C) 2019 Unit Riset dan Publikasi Ilmiah FTK UIN Raden Intan Lampung

Kata Kunci: model pembelajaran, model advance organizer, hasil belajar kognitif 


\section{PENDAHULUAN}

Pendidikan merupakan sesuatu yang memiliki tujuan yang sangat penting untuk diperoleh. Pendidikan merupakan hal yang sangat penting untuk meningkatkan dan mengembangkan kualitas sumber daya manusia (Selly, Diana, \& Yuberti, 2018). Dalam skala nasional, tujuan dalam pendidikan adalah untuk mengembangkan kemampuan dan membentuk watak serta peradaban bangsa yang bermartabat dalam rangka mencerdaskan kehidupan bangsa, serta untuk mengembangkan potensi peserta didik agar menjadi manusia yang beriman dan bertaqwa kepada Tuhan Yang Maha Esa , berakhlak mulia, sehat, berilmu, cakap, kreatif, mandiri serta menjadi warga Negara yang demokratis serta bertanggung jawab (Undang-undang Republik Indonesia Nomor 20 Tahun 2003.2006).

Sering dikatakan bahwa fisika adalah mata pelajaran yang sulit karena penggunaan matematika didalamnya, atau karena peserta didik tidak bisa menghitung, atau fisika tidak menarik, sehingga berpengaruh terhadap hasil belajar peserta didik. Ada beberapa faktor yang membuat hasil belajar fisika peserta didik itu rendah, diantaranyanya kurangnya minat belajar siswa untuk mengetahui keterampilan hasil belajar akademik tinggi dan rendah (Ananto \& Yuberti, 2018). Penelitian dari dua kadulawarsa dan sejarah, fisika memperlihatkan bahwa salah satu sumber kesulitan utama adalah terjadinya miskonsepsi (Mustari, 2015).

Setelah melakukan observasi di SMK Kautsar Karang Pucung sesuai dengan pedoman wawancara yang dilampirkan maka didapatkan masalah yaitu rendahnya kemampuan kognitif peserta didik, sehingga hasil belajarkognitif peserta didik masih kurang atau masih dibawah nilai KKM. Berdasarkan hasil wawancara dengan ibu Yunita,S.Pd sebagai pendidik di SMK Kautsar Karang Pucung
Lampung Selatan bidang studi Fisika ternyata peserta didik masih sangat lemah dalam menguasai materi/memahami materi yang dijelaskan oleh pendidik, peserta didik tidak bisa mengerjakan soal yang dikecoh, mereka hanya bisa mengerjakan soal hitungan yang mirip dengan contoh soal. Tetapi ketika soal tersebut diubah yang ditanya menjadi yang diketahui maka peserta didik menjadi bingung dan merasa permasalahan tersebut tidak pernah dibahas.Sehingga hasil belajar kognitif peserta didik pun tidak banyak yang mecapai KKM.

Tabel 1. Data Hasil Pretest Materi Fluida

\begin{tabular}{lccc}
\hline No & Nilai & Jumlah & Presentase \\
\hline 1. & $\geq \mathbf{6 5}$ & 7 & $21,9 \%$ \\
2. & $\leq \mathbf{6 5}$ & 25 & $78,1 \%$ \\
& Jumlah & 32 & $100 \%$ \\
\hline
\end{tabular}

Gambaran tingkah laku dan hasil pembelajaran adalah struktur kognitif. Hal ini menjelaskan bahwa peserta didik bermasalah pada kemampuan kognitifnya terlihat dari perilaku meniru dan ketidakmampuan peserta didik dalam mengerjakan soal-soal latihan sesuai dengan konsepnya, dan semakin jelas terlihat pada hasil belajar kognitif peserta didik yang sangat rendah (Abdurrahman, 2017). Perubahan tingkah laku peserta didik dapat diketahui dari hasil belajar yang didapatkan, baik pada ranah pengetahuan (kongnitif), sikap (afektif), maupun keterampilan (psikomotor) (Diani, Yuberti, \& Syafitri, 2016).

Hasil belajar fisika peserta didik juga dipengaruhi oleh pendidik dalam kegiatan pembelajaran. Kegiatan pembelajaran kurang bervariasi dalam model ataupun metode yang digunakan. Kemampuan bertanya peserta didik dan kualitas pembelajaran juga masih kurang, kelas cenderung pasif (Asmawati, 2015). Hal tersebut membuat peserta didik bosan dalam mengikuti pembelajaran (Widiyatmoko, 2012).

Model pembelajaran sangat diperlukan dalam memberikan dasardasar konsep peserta didik. Model 
pembelajaran yang tepat akan memberikan proses pembelajaran yang lebih aktif serta peserta didik mampu menyelesaikan permasalahan dalam pembelajaran. Pembelajaran merupakan suatu sistem yang terdiri atas berbagai komponen yang saling berhubungan satu dengan yang lain (Mustari, 2016).

Advance Organizer menjadi metode pembelajaran yang efektif meningkatkan kemampuan berpikir disebabkan empat hal : 1) Advance Organizer mengaktifkan kembali konsep yang relevan dalam struktur kognitif belajar, 2) konsep abstrak yang relevan itu merupakan tempat untuk mengaitkan ide baru (ideational scaffolding), 3) konsep yang rinci dan konkret yang terdapat dalam materi yang akan dipelajari (learning task) diterima oleh peserta didik ke dalam struktur kognitifnya, 4) dengan menggunakan kemampuan intelektualnya, serta kemampuan menghubungkan konsep baru dan lama, peserta didik selanjutnya memahami isinya, karena bahan yang dipelajari menjadi bagian baru dari struktur kognitif peserta didik, sedangkan konsep yang tidak terpakai akan hilang ke dalam alam bawah sadar peserta didik (S. E. Nugroho, 2014).

Advance Organizer merupakan salah satu konsep pembelajaran untuk membantu pendidik memberikan pertolongan mental dan disajikan sebelum materi baru (Sinulingga \& Munte, 2012). Model advance organizer menitik beratkan pada bagaimana proses peserta didik mengaitkan pengetahun baru dengan pengetahuan sebelumnya yang mengakibatkan struktur kognitif peserta didik menjadi lebih baik sehingga muncul belajar bermakna (Alamsyah \& Turmudi, 2016).

Hasil dari wawancara juga disebutkan beberapa kesulitan lainnya, kesulitan- kesulitan tersebut tampak dalam beberapa hal; pertama, dalam proses pembelajaran peserta didik sering kali tidak mampu mengaitkan konsep- konsep yang mereka pelajari, akibatnya mereka mengalami hambatan dalam menyelesaikan tugas-tugas yang diberikan oleh pendidik; kedua, hasil ujian fisika umumnya masih di bawah Kriteria Ketuntasan Minimal KKM. Jika dilihat dari Kriteria Ketuntasan Minimal (KKM) pada mata pelajaran fisika yang ditetapkan di sekolah tersebut adalah 65; ketiga peserta didik menjadi pasif karena bertindak sebagai pendengar saja, pendidik masih menjadi pemeran utama dalam kegiatan pembelajaran sehingga materi yang diberikan oleh pendidikpun kurang dipahami oleh peserta didik.

Dari uraian tersebut, peneliti termotivasi untuk melakukan suatu penelitian dengan judul "Pengaruh Model Pembelajaran Advance Organizer untuk Meningkatkan Kemampuan Kognitif Peserta Didik Pokok Bahasan Fluida Dinamis SMK".

\section{METODE PENELITIAN}

Jenis penelitian yang digunakan adalah Quasi experimen yaitu desain yang memiliki kelompok kontrol tetapi tidak berfungsi sepenuhnya untuk mengontrol variabel-variabel luar yang mempengaruhi pelaksanaan eksperimen (Sugiyono, 2011). Quasi-eksperimental design yang digunakan adalah jenis NonEquivalent Control Group design pada desain ini terdapat pretest dan posttest untuk kelompok eksperimen dan noneksperimen.

Tabel 2. Control Group Pretest-postest

\begin{tabular}{cccc}
\hline Kelompok & $\begin{array}{c}\text { Tes } \\
\text { Awal }\end{array}$ & $\begin{array}{c}\text { Perlakuan } \\
(\mathbf{x})\end{array}$ & $\begin{array}{c}\text { Tes } \\
\text { Akhir }\end{array}$ \\
\hline Eksperimen & $T_{1}$ & $\mathrm{X}$ & $T_{2}$ \\
\hline $\begin{array}{c}\text { Non- } \\
\text { Eksperimen }\end{array}$ & $T_{1}$ & - & $T_{2}$ \\
\hline
\end{tabular}

Keterangan:

$\mathrm{X}$ : Perlakuan dengan model pembelajaran Advance Organizer

$T_{1}$ : Preetest (tes awal sebelum proses belajar mengajar dimulai dan belum diberikan perlakuan). 
$T_{2}$ : Posttest (tes akhir setelah proses belajaar mengajar berlangsung dan diberikan perlakuan).

\section{Uji Coba Instrumen Penelitian}

\section{Uji Validitas}

Untuk menguji validitas digunakan rumus :

$\mathbf{r}_{\mathrm{xy}}=\frac{N \sum X Y-\left(\sum X\right)\left(\sum Y\right)}{\sqrt{\left\{N X^{2}-\left(\sum X\right)^{2}\right\}\left\{N Y^{2}-\left(\sum Y\right)^{2}\right\}}}$

Keterangan :

\begin{tabular}{|c|c|}
\hline$r_{x y}$ & $\begin{aligned}= & \text { Koefisien Korelasi } \\
& \text { antara variabel X dan }\end{aligned}$ \\
\hline \multicolumn{2}{|l|}{$\mathrm{Y}$} \\
\hline $\mathrm{N}$ & $=$ Jumlah responden \\
\hline$\sum X$ & $=$ Jumlah pertanyaan \\
\hline$\sum Y$ & $=$ Jumlah skor total \\
\hline$\sum X Y$ & $\begin{aligned}= & \text { Jumlah perkalian dari } \\
& \text { variabel } \mathrm{X} \text { dan } \mathrm{Y}\end{aligned}$ \\
\hline$\sum X^{2}$ & $\begin{aligned}= & \text { Jumlah kuadrat dari } \\
& \text { pertanyaan }\end{aligned}$ \\
\hline & Jumlah kuadra \\
\hline
\end{tabular}

Jika $r_{x y} \leq r_{\text {tabel }}$ maka soal dikatakan tidak valid dan jika $r_{x y} \geq r_{\text {tabel }}$ maka soal dikatakan valid. Interprestasi terhadap nilai koefisien $r_{x y}$ digunakan kriteria pada tabel 1 .

Tabel 3. Interpretasi Korelasi $\mathrm{r}_{\mathrm{xy}}$

\begin{tabular}{cc}
\hline Nilai $\mathbf{r}_{\mathbf{x y}}$ & Keterangan \\
\hline $\mathrm{r}_{\mathrm{xy}}<0,349$ & Tidak Valid \\
\hline $\mathrm{r}_{\mathrm{xy}} \geq 0,349$ & Valid \\
\hline
\end{tabular}

\section{Uji Reabilitas}

Reliabel berarti dapat dipercaya.

$$
\mathbf{r}_{11}=\left(\frac{n}{(n-1)}\right)\left(1-\frac{\sum \sigma_{i}^{2}}{\sigma_{i}^{2}}\right)
$$

Keterangan :

$$
\begin{aligned}
& \mathrm{r}_{11} \quad=\text { reliabilitas instrument } \\
& \sum \sigma_{i}^{2} \quad=\text { jumlah varians item } \\
& \sigma_{i}^{2} \quad=\text { varians total }
\end{aligned}
$$

(Arikunto, 2013)

Tabel 4. Klasifikasi Koefisien Reliabilitas

\begin{tabular}{cc}
\hline $\begin{array}{c}\text { Kriteria } \\
\text { Korelasi }\end{array}$ & $\begin{array}{c}\text { Kriteria } \\
\text { Reliabilitas }\end{array}$ \\
\hline $0,00-0,20$ & Sangat rendah \\
$0,20-0,40$ & Rendah \\
$0.40-0,70$ & Sedang \\
$0,70-0,90$ & Tinggi \\
$0,90-1,00$ & Sangat tinggi \\
\hline
\end{tabular}

\section{Uji Tingkat Kesukaran}

Bilangan yang menunjukkan sukar dan mudahnya suatu soal disebut indeks kesukaran (difficulty index).

Keterangan :

$$
\mathrm{P}=\frac{B}{J S}
$$

\begin{tabular}{ccc}
$\mathrm{P}$ & $=$ & Indeks kesukaran \\
$\mathrm{B}$ & $=$ Banyaknya siswa yang \\
& menjawab soal itu dengan betul \\
JS & = Jumlah seluruh siswa peserta tes \\
& Indeks kesukaran dapat \\
& diklasifikasikan (Sudijono, 2015) \\
& Tabel 5. Tingkat Kesukaran \\
\hline Besar P & Interprestasi \\
\hline & $\mathrm{P}<0,30$ & Sukar \\
$0,31 \leq \mathrm{P} \geq 0,70$ & Cukup (Sedang) \\
$\mathrm{P}>0,71$ & Mudah \\
\hline
\end{tabular}

\section{Uji Daya beda}

Daya pembeda soal adalah kemampuan sesuatu soal untuk membedakan antara siswa yang berkemampuan tinggi dengan siswa yang berkemampuan rendah.

Keterangan :

$$
\mathrm{D}=\frac{B_{A}}{j_{A}}-\frac{B_{B}}{j_{B}}
$$

$$
\begin{aligned}
& \mathrm{D}=\text { Daya pembeda } \\
& j_{A} \quad=\text { Banyaknya peserta } \\
& \text { kelompok atas } \\
& =\text { Banyaknya peserta } \\
& \text { kelompok bawah } \\
& B_{A} \quad=\text { Banyaknya peserta } \\
& \text { kelompok atas yang } \\
& \text { menjawab soal itu dengan } \\
& \text { benar } \\
& B_{B} \quad=\text { Banyaknya peserta } \\
& \text { kelompok bawah yang } \\
& \text { menjawab soal itu } \\
& \text { dengan benar }
\end{aligned}
$$

Tabel 6. Klasifikasi Daya Beda

\begin{tabular}{cc}
\hline Besarnya Nilai D & Kriteria \\
\hline $0,00-0,20$ & Jelek \\
$0,21-0,30$ & Cukup \\
$0,31-0,70$ & Baik \\
$0,71-1,00$ & Baik sekali \\
\hline
\end{tabular}




\section{Teknik Analisis Data}

1. Teknik Analisis Data Peningkatan Kemampuan Kognitif

Nilai N Gain berfungsi untuk mengetahui kemampuan kognitif peserta didik.

$\mathrm{N}-$ Gain Indeks Gain $=\frac{\text { skor pretest-skor pretest }}{\text { skor } \text { maksimal-skor pretest }}$ (Jumiati, Martala, \& Dian, 2011)

Tabel 7. Kategori N-Gain/Indeks Gain

\begin{tabular}{cc}
\hline Batasan & Kategori \\
\hline $\mathrm{g}>0,7$ & Tinggi \\
$0,3<\mathrm{g} \leq 0,07$ & Sedang \\
$\mathrm{g} \leq 0,3$ & Rendah \\
\hline
\end{tabular}

\section{Uji Prasyarat}

\section{a. Uji Normalitas}

Uji normalitas data dilakukan untuk mengetahui apakah data yang diperoleh dari populasi yang berdistribusi normal atau tidak dengan menggunakan rumus uji Kolmogorov smirnov test dengan program SPSS 21.0.

1) Hipotesis

$H_{o}$ : Sampel berasal dari populasi yang berdistribusi normal

$H_{1}$ : Sampel tidak berasal dari populasi yang berdistribusi normal

2) Taraf Signifikan $(\alpha)=0,05$

Kesimpulan : Jika nilai sig $>0.05$, maka

$\mathrm{H}_{\mathrm{o}}$ diterima (sampel berdistribusi normal).

\section{b. Uji Homogenitas}

Uji homogenitas digunakan untuk mengetahui apakah populasi penelitian mempunyai variansi yang sama atau tidak. Uji homogenitas yang digunakan adalah uji homogenitas dua varians atau uji fisher yaitu :

Keterangan:

$$
\mathrm{F}=\frac{S 1^{2}}{S 2^{2}}
$$

F : Homogenitas

$\mathrm{S}_{1}^{2}$ : Varian terbesar

$\mathrm{S}_{2}^{2}$ : Varian terkecil

1) Uji hipotesisnya :

Ho : $\sigma_{1}^{2}=\sigma_{1}^{2} \quad$ (kedua varians mempunyai varians yang sama)

$\mathrm{Ha} \quad: \quad \sigma_{1}^{2} \neq \sigma_{1}^{2} \quad$ (kedua sampel mempunyai varians yang berbeda)
2) Taraf signifiknan $(\alpha)=0,05$

Kesimpulan: Dengan menentukan nilai signifikan sesuai kriteria sebagai berikut: $\mathrm{H}_{0}$ diterima jika nilai sig $>0.05 \mathrm{H}_{0}$ : data yang memiliki varian homogen.

$\mathrm{H}_{0}$ ditolak jika nilai sig $<0.05 \mathrm{H}_{0}$ : data yang tidak memiliki varian homogen.

\section{c. Uji Hipotesis}

1) Pengujian Secara Parsial (Uji-t)

Uji statistik t disebut juga dengan uji parsial. Uji ini menunjukan seberapa jauh pengaruh variabel bebas terhadap variabel terikatnya. Bentuk pengujiannya adalah sebagai berikut:

$\boldsymbol{H}_{\mathbf{0}}$ : $\quad$ Tidak terdapat pengaruh yang signifikan sehingga tidak terjadi peningkatan pada kemampuan kognitif peserta didik yang menggunakan model pembelajaran Advance Organizer kelas XI SMK Kautsar Karang Pucung Lampung Selatan.

$\boldsymbol{H}_{\mathbf{1}}$ : Terdapat pengaruh yang signifikan sehingga terjadi peningkatan pada kemampuan kognitif peserta didik yang menggunakan model pembelajaran Advance Organizer kelas XI SMK Kautsar Karang Pucung Lampung Selatan.

Tingkat kepercayaan yang digunakan adalah $95 \%$, maka nilai $a=0.05$.

Dasar pengambilan keputusan dalam uji-t pertama menggunakan SPSS 21.0 adalah: $\mathrm{H}_{\mathrm{o}} \quad$ diterima dan $\mathrm{H}_{1}$ ditolak jika nilai t hitung $<\mathrm{t}$ table atau jika nilai sig. $>$ 0.05 .

$\mathrm{H}_{\mathrm{o}} \quad$ ditolak dan $\mathrm{H}_{1}$ diterima jika nilai $\mathrm{t}$ hitung $>\mathrm{t}$ table atau jika nilai sig. $<$ 0.05 .

\section{Lembar Observasi Keterlaksanaan Model}

Instrumen non tes penelitian ini berupa lembar observasi. Observasi yang dilakukan adalah observasi keterlaksanaan model pembelajaran advance organizer. Persentase observasi keterlaksanaan model pembelajaran advance organizer menggunakan skala Likert, maka persentase analisisnya 


\begin{tabular}{|c|c|c|}
\hline \multicolumn{3}{|c|}{$\begin{array}{l}\text { menggunakan rumus dan kriter } \\
\text { interpretasi nilai sebagai berikut. } \\
\text { Nilai Persentase }=\frac{\text { Jumlah skor yang diperoleh }}{\text { Jumlah skor maksimal }} \times \\
100 \% \\
\text { Tabel 8. Kriteria Interpretasi Nilai Observasi }\end{array}$} \\
\hline No & Persentase (\%) & Kategori \\
\hline 1 & $81-100$ & Sangat Baik \\
\hline 2 & $61-80$ & Baik \\
\hline 3 & $41-60$ & Cukup \\
\hline 4 & $21-40$ & Kurang \\
\hline 5 & $0-20$ & Sangat Kurang \\
\hline
\end{tabular}

Kriteria interpretasi nilai observasi ini dikemukakan oleh Koentjaraningrat (1990) dalam (Maradona).

\section{HASIL DAN PEMBAHASAN}

\section{A. Hasil Uji Coba}

\section{Uji Validitas}

Uji validitas soal kemampuan kognitif peserta didik dapat dilihat pada tabel 9

Tabel 9. Uji validitas Butir Soal

\begin{tabular}{cc}
\hline Kategori & No soal \\
\hline Valid & $1,2,3,6,7,8,11,12,14,15,17,19,21,2$ \\
& $2,23,26,29,31,34,35,37,38,40$. \\
Tidak & $4,5,9,10,13,16,18,20,24,25,27,28$, \\
Valid & $30,32,33,36,, 39$. \\
\hline
\end{tabular}

Berdasarkan tabel hasil perhitungan tersebut terdapat 40 soal yang diuji cobakan dengan responden 32 peserta didik. Tes uji coba dari 40 soal diperoleh 23 soal yang dikatakan valid dan yang digunakan adalah 20 soal, sebab $r_{x y}$ $\geq 0,349$ dan terdapat soal yang tidak valid sebab $r_{x y} \leq 0,349$.

\section{Uji Reabilitas}

Uji reabilitas digunakan untuk mengetahui sejauh mana hasil pengukuran tetap konsisten dan item soal dapat digunakan kembali atau tidak. Suatu tes dapat dikatakan baik jika reabilitas sama dengan atau lebih dari 0,70. Berdasarkan hasil perhitungan, menunjukkan bahwa tes kemampuan kognitif tersebut memiliki indeks reliabilitas sebesar 0.8234 , dengan demikian tes tersebut memiliki reliabilitas yang tinggi sehingga tes tersebut layak digunakan untuk mengambil data.

\section{Uji Tingkat Kesukaran}

Berikut adalah hasil analisis uji tingkat kesukaran.

Tabel 10. Hasi Uji Tingkat Kesukaran

\begin{tabular}{cc} 
Kriteria & No soal \\
\hline Sukar & 0 \\
Sedang & $2,3,4,5,6,7,8,9,10,11,13,14,15$, \\
& $16,17,18,19,20,21,22,23,24,25$, \\
& $26,27,28,29,30,32,33,34,35,36$, \\
& $37,38,39,40$ \\
Mudah & $1,12,31$ \\
\hline
\end{tabular}

Berdasarkan hasil tingkat kesukaran butir soal, diperoleh 3 soal kriteria mudah dan 37 soal kriteria sedang untuk kemampuan kognitif peserta didik.

\section{Uji Daya Pembeda}

Uji daya pembeda digunakan untuk mengetahui seberapa jauh kemampuan butir soal dapat membedakan antara peserta didik yang menjawab dengan benar kelompok atas dengan kelompok bawah. Berikut ini adalah hasil analisis daya pembeda.

Tabel 11. Daya Pembeda

\begin{tabular}{cc}
\hline Kriteria & No Soal \\
\hline Tidak baik & $2,4,5,10,13,16,18,20,21,22,26,2$ \\
& $9,30,31,32,33,35,37,38,39$ \\
Cukup & $1,17,24,25,27,36$ \\
Baik & $3,6,7,8,9,11,12,14,15,19,23,28,3$ \\
& 4,40 \\
Baik & 0 \\
Sekali & \\
\hline
\end{tabular}

Berdasarkan hasil perhitungan daya pembeda butir soal, diperoleh 14 soal dengan kriteria baik, 20 soal dengan kriteria tidak baik dan 6 soal dengan kriteria cukup pada kemampuan kognitif peserta didik.

\section{B. Deskripsi Data Kemampuan Kognitif}

Nilai rata-rata pretest kelas kontrol dan kelas eksperimen dapat dilihat pada

Tabel 12. Hasil Pretest Kemampuan kognitif peserta didik

\begin{tabular}{cc}
\hline Kelas & Rata-rata Nilai \\
\hline Kontrol & 40.16 \\
Eksperimen & 47 \\
\hline
\end{tabular}


Berdasarkan Tabel diatas nilai pretest untuk materi fluida dinamis masih tergolong rendah, dan belum memenuhi KKM untuk mata pelajaran Fisika.

Hasil nilai rata-rata posttest kelas kontrol dan kelas eksperimen dapat dilihat pada tabel 13 sebagai berikut:

Tabel 13. Hasil Posttest Kelas Eksperimen dan Kelas Kontrol

\begin{tabular}{cc}
\hline Kelas & Rata-rata Nilai \\
\hline Eksperimen & 81.93 \\
Kontrol & 56 \\
\hline
\end{tabular}

Berdasarkan hasil posttest kelas eksperimen dan kelas kontrol menunjukkan bahwa kelas eksperimen lebih tinggi dibandingkan dengan kelas kontrol. Selanjutnya untuk mengkategorikan hasil kemampuan kognitif peserta didik digunakan skor NGain. Skor ini digunakan untuk mengetahui nilai kemampuan peserta didik. Hasil N-Gain belajar peserta didik dari kelas eksperimen dan kelas kontrol dapat dilihat pada tabel 14 sebagai berikut.

Tabel 14. Hasil N-Gain Kelas Eksperimen dan Kelas Kontrol

\begin{tabular}{cccc}
\hline Aspek & Jenis Kelas & N-Gain & Kriteria \\
\hline Kemampuan Kognitif & Eksperimen & 0.7 & Sedang \\
Peserta Didik & Kontrol & 0.23 & Rendah
\end{tabular}

Berdasarkan tabel di atas menunjukkan bahwa nilai rata-rata N-Gain kelas eksperimen lebih tinggi dibandingkan dengan kelas kontrol. Sedangkan untuk kategorinya sedang untuk kelas eksperimen dan rendah kelas kontrol.

\section{Pengujian Prasyarat Analisis \\ 1. Uji Normalitas}

Analisis uji normalitas dilakukan dengan menggunakan Kolmogorov smirnov test dari program SPSS 21.0. (dengan taraf signifikan $=0,05$ ). Hasil menunjukkan data terdistribusi normal.

Tabel 15. Hasil Analisis Uji Normalitas

\begin{tabular}{|c|c|c|c|}
\hline Variabel & Kelas & $\begin{array}{l}\text { Kelomp } \\
\text { ok Data }\end{array}$ & $\begin{array}{c}\text { Nilai } \\
\text { Sig }\end{array}$ \\
\hline Kemampuan & Eksperim & Pretest & 0.322 \\
\hline Kognitif & en & Posttest & 0.186 \\
\hline Peserta & & Pretest & 0.271 \\
\hline Didik & Kontrol & Posttest & 0.370 \\
\hline
\end{tabular}

Berdasarkan Tabel 15, maka dapat dilihat data kemampuan kognitif peserta didik kelas eksperimen kelompok data pretest memperoleh nilai signifikan $0.322>0.05$, dan pada kelompok data posttest memperoleh nilai signifikan $0.186>0.05$. Serta data kemampuan kognitif peserta didik kelas kontrol kelompok data pretest memperoleh nilai signifikan $0.271>0.05$, dan pada kelompok data posttest memperoleh nilai signifikan $0.370>0.05$. Sehingga keseluruhan kelompok data menunjukkan nilai signifikansi $>0.05$.
Oleh karena nilai signifikan $>0.05$, maka $\square_{0}$ diterima yang berarti kelompok data pretest dan posttest pada kelas eksperimen dan kelas kontrol adalah berdistribusi normal.

\section{Uji Homogenitas}

Uji homogenitas digunakan untuk mengetahui apakah beberapa varians populasi data adalah sama atau tidak. Uji ini dilakukan sebagai prasyarat yang kedua untuk menentukan uji hipotesis yang digunakan. Berdasarkan perhitungan yang telah dilakukan menggunakan SPSS 21.0 diketahui nilai signifikansi (sig) based on mean sebesar $0.172>0.05$, berarti nilai signifikan yang diperoleh pada uji homogenitas lebih besar dibandingkan dengan taraf signifikansi yang ditentukan yaitu 0.05 sehingga dapat disimpulkan bahwa varians data posttest kelas eksperimen dan data posttest kelas control adalah sama atau homogen.

\section{Hasil Pengujian Hipotesis}

Berdasarkan hasil uji normalitas dan homogenitas yang telah dilakukan menunjukkan bahwa data berdistribusi normal dan homogen, maka selanjutnya data dianalisis untuk pengujian hipotesis. Perhitungan uji hipotesis dilakukan untuk mengetahui ada atau tidaknya pengaruh signifikansi dalam pembelajaran yang 
menggunakan model pembelajaran advance organizer terhadap peningkatan kemampuan kognitif peserta didik. Pengujian hipotesis dalam penelitian ini menggunakan uji t.

Berdasarkan hasil tes kemampuan kognitif peserta didik kelas eksperimen diperoleh hasil output menggunakan SPSS 21.0. Data lengkap hasil perhitungan uji-t dapat dilihat pada lampiran 24 halaman 195. Nilai signifikan pretest dan posttest kelas eksperimen adalah 0.000 , dengan demikian $0.000<$ 0.05 atau nilai signifikansi lebih kecil dari 0.05 ini berarti Ho ditolak dan $\mathrm{H} 1$ diterima. Artinya jika H1 diterima maka terdapat pengaruh yang signifikan terhadap kemampuan kognitif peserta didik yang menggunakan model pembelajaran Advance Organizer kelas XI SMK Kautsar Karang Pucung Lampung Selatan. Lebih jelasnya dapat dilihat pada table berikut.

Table 16. Rekapitulasi Hasil Perhitungan Uji Hipotesis

\begin{tabular}{lllll}
\hline Kelompok & $\begin{array}{l}\text { Jumlah } \\
\text { Sampel }\end{array}$ & Nilai sig. & Ket \\
\hline
\end{tabular}

\begin{tabular}{ccccc} 
Eksperimen & 31 & 0.05 & 0.000 & $\begin{array}{c}\text { H0 ditolak dan } \\
\text { H1 diterima }\end{array}$ \\
\cline { 1 - 3 } & 31 & 0.05 & 0.000 & \\
\hline Kontrol & Observasi & maka persentase &
\end{tabular}

\section{E. Analisis Hasil Observasi Keterlaksanaan Model Pembelajaran Advance Organizer}

Lembar observasi digunakan sebagai instrumen penelitian untuk mengukur keterlaksanaan model pembelajaran advance organizer pada pokok bahasan bunyi yang dilakukan oleh peneliti. Pada penelitian ini lembar observasi diukur menggunakan skala Likert yang diisi oleh guru mata pelajaran fisika sebagai observer. Hasil keterlaksanaan model pembelajaran advance organizer pada empat kali pertemuan dapat dilihat pada Tabel 16.

Tabel 17. Hasil Observasi Keterlaksanaan Model Pembelajaran Advance Organizer

\begin{tabular}{|c|c|c|c|}
\hline \multicolumn{3}{|c|}{ Pertemuan Skor Persentase } & \multirow{2}{*}{$\begin{array}{c}\text { Kategori } \\
\text { Sangat } \\
\text { Baik }\end{array}$} \\
\hline Ke-1 & 89 & $89 \%$ & \\
\hline Ke-2 & 82 & $91,1 \%$ & $\begin{array}{c}\text { Sangat } \\
\text { Baik }\end{array}$ \\
\hline Jumlah & 171 & $90,05 \%$ & $\begin{array}{r}\text { Sangat } \\
\text { Baik }\end{array}$ \\
\hline
\end{tabular}

Pada Tabel 17 menunjukkan bahwa persentase observasi keterlaksanaan model pembelajaran advance organizer pada pertemuan pertama sebesar $89 \%$ termasuk dalam kategori sangat baik, persentase pada pertemuan kedua sebesar 91,1\% termasuk dalam kategori sangat baik. Berdasarkan dari kedua pertemuan maka persentase rata-rata hasil observasi sebesar 90,05\%, sehingga dapat disimpulkan bahwa pada kelas eksperimen keterlaksanaan model pembelajaran advance organizer terlaksana dengan sangat baik.

Peneliti bertindak sebagai pendidik dalam pembelajaran di sekolah, baik pada kelas eksperimen ataupun pada kelas kontrol. Kelas eksperimen disini menggunakan pembelajaran model advance organizer dan kelas kontrol menggunakan pembelajaran model direct instruction. Penelitian ini dilakukan selama empat kali pertemuan dengan materi fluida dinamis. Kelas yang dgiunakan merupakan kelas XI TKJ A (eksperimen) yang terdiri dari 31 peserta didik dan XI TKJ B (kontrol)yang terdiri dari 31 peserta didik.

Pada pertemuan pertama, kelas eksperimen dan kelas kontrol diberikan pretest materi fluida dinamis untuk mengetahui hasil kemampuan kognitif peserta didik sebelum diberikannya perlakuan dari kedua kelas tersebut. Hasil kemampuan kognitif pada pretest kelas eksperimen memperoleh skor rata-rata 40.16 dan pada kelas kontrol diperoleh nilai rata-rata 47. Hal tersebut menunjukkan bahwa tidak ada pengaruh 
yang signifikan terhadap kedua kelas tersebut, karena kedua kelas tersebut belum mendapatkan perlakuan.

Pada pertemuan kedua, pembelajaran di kelas eksperimen diberikan perlakuan dengan menerapkan model pembelajaran advance organizer, sedangkan pada kelas kontrol menggunakan model pembelajaran direct instruction (konvensional) yang biasa diterapkan pendidik disekolah tersebut. Pada kelas eksperimen pembelajaran menggunakan model advance organizer dilakukan sebanyak dua kali pertemuan selain dari pretest dan posttest atau sampai dengan pertemuan ketiga pada pokok bahasan fluida dinamis. Pada kelas kontrol juga pembelajaran menggunakan model direct instruction (konvensional) dilakukan sebanyak dua kali pertemuan selain dari pretest dan posttest atau sampai dengan pertemuan ketiga dengan pokok bahasan yang sama yaitu fluida dinamis.

Pada pertemuan keempat, setelah dilakukan perlakuan pada kelas eksperimen dan kelas kontrol dengan pokok bahasan fluida dinamis, kemudian kedua kelas tersebut diberikan posttest, tujuan dari posttest iniuntuk mengetahui atau mengukur peningkatan kemampuan kognitif yang diperoleh peserta didik dan melihat apakah terdapat pengaruh yang signifikan dengan menggunakan model pembelajaran advance organizer. Hasil kemampuan kognitif yang diperoleh peserta didik pada kelas eksperimen yaitu memperoleh nilai rata-rata 81.93 dan pada kelas kontrol memperoleh nilai rata-rata 56. Dari hasil rata-rata nilai yang diperoleh dapat dilihat bahwa peningkatan nilai yang diperoleh kelas eksperimen lebih tinggi dibandingkan dengan nilai yang diperoleh kelas kontrol. Sehingga dapat disimpulkan bahwa terdapat pengaruh yang lebih baik dengan menggunakan model pembelajaran advance organizer dibandingkan dengan menggunakan model pembelajaran direct instruction (konvensional).
Nilai rata-rata kemampuan kognitif peserta didik dari pretest dibandingkan dengan nilai rata-rata kemampuan kognitif peserta didik dari posttest pada kelas eksperimen dan kelas kontrol masing-masing mengalami peningkatan. Hasil perhitungan N-Gain kemampuan kognitif peserta didik kelas eksperimen sebesar 0.70 termasuk klasifikasi sedang, sedangkan pada kelas kontrol sebesar 0.23 termasuk klasifikasi rendah. Sehingga peningkatan kemampuan kognitif peserta didik pada kelas eksperimen yang menggunakan model pembelajaran advance organizer lebih tinggi dibandingkan dengan kelas kontrol yang menggunakan model direct instruction (konvensional).

Peningkatan N-Gain ini sesuai dengan hasil penelitian yang terdahulu bahwa penggunaan strategi metakognitif berbantu Advance Organizer terbukti efektif terhadap peningkatan hasil belajar siswa suatu SMA di Tengaran kelas X-5 pada materi hidrokarbon. Penggunaan strategi metakognitif berbantu Advance Organizer efektif meningkatkan hasil belajar siswa kelas eksperimen pada aspek kognitif, afektif dan psikomotorik secara signifikan (Namira, Kusumo, \& Prasetya, 2014).

Sedangkan pembelajaran pada kelas eksperimen dan kelas kontrol juga dapat dilihat hasil penelitian yeng terdahulu yang menyimpulkan bahwa terdapat perbedaan hasil belajar Fisika antara peserta didik yang menggunakan model pembelajaran Advance Organizer berbasis eksperimen dibandingkan dengan peserta didik yang menggunakan model pembelajaran Direct Instruction (Sungkawan, 2013).

Tasiwa menyimpulkan bahwa dari kegiatan penelitian diperoleh peserta didik ekperimen dengan advance organizer berbasis proy- ek memiliki tingkat motivasi lebih baik daripada kelas kontrol. Persentase peserta didikkelas eksperimen dengan motivasi kategori $\mathrm{A}$ 
(sangat baik) dan B (baik) pada tiap aspeknya, lebih besar daripada kelas control (T. S. . Nugroho \& Hartono, 2014).

Adapun kelebihan dan kekurangan dalam pelaksanaan penelitian ini, adalah sebagai berikut: dapat meningkatkan kemampuan kognitif peserta didik, menumbuhkan kepercayaan diri peserta didik dalam proses pembelajaran, peserta didik memperoleh pengetahuan yang bersifat sangat pribadi individual sehingga kokoh dalam ingatan peserta didik, membangkitkan kegairahan belajar peserta didik, dan pembelajaran berpusat pada peserta didik, guru hanya sebagai fasilisator. Kekurangan dalam penelitian ini: peserta didik baru mengenal model advance organizer sehingga pelaksanaannya sedikit terhambat, waktu penelitian yang terbatas sehingga pelaksanaan pembelajaran kurang optimal, kurang seriusnya peserta didik dalam mengikuti pembelajaran karena peserta didik menganggap peneliti sebagai guru pengajar dan hasil dari peneliti tidak mempengaruhi nilai rapor peserta didik, kelas terlalu besar sehingga pembelajaran kurang efektif.

Berdasarkan pengujian hipotesis menggunakanoutput SPSS 21.0 uji t pada taraf signifikan $\square=0,05$ kepercayaan $=95$ $\%$, pada kemampuan kognitif peserta didik diperoleh nilai signifikansi 0.000 atinya nilai signifikansi $<$ taraf signifikan atau $0.000<0.05$, dan diperoleh hasil $\square_{\square \square \square \square \square}$ sebesar 2.045 dan $\square_{h \square \square \square \square \square}$ sebesar 21.921 sehingga terbukti bahwa

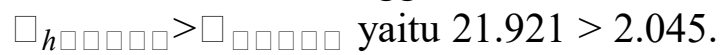
Berdasarkan hasil perhitungan diperoleh kesimpulan bahwa peningkatan kemampuan kognitif peserta didik kelas eksperimen menggunakan model pembelajaran advance organizer lebih tinggi dari pada peningkatan kemampuan kognitif peserta didik kelas control dengan model konvensional yaitu model pembelajaran direct instruction. Artinya pembelajaran dengan model advance organizer berpengaruh terhadap kemampuan kognitif peserta didik, hal ini karena pada pembelajaran menggunakan advance organizer lebih menekankan struktur kognitif pada peserta didik sehingga berpengaruh terhadap peningkatan hasil kemampuan kognitif peserta didik. Sedangkan pada model pembelajaran konvensional yaitu dengan model direct instruction peserta didik hanya di tuntut untuk menerima yang disampaikan oleh guru, sehingga peserta didik cenderung pasif. Hal ini dibuktikan dengan terjawabnya hipotesis penelitian yaitu pembelajaran dengan menggunakan model advance organizer memberikan pengaruh yang signifikan terhadap peningkatan kemampuan kognitif peserta didik pada pokok bahasan fluida dinamis.

Peserta didik dapat mengkonstruksi sendiri pengetahuannya, karena pada pembelajaran menggunakan model advance organizer peserta didik di tuntut secara mandiri dan benar-benar mempelajari materi fluida dinamis secara mendalam sendiri, peserta didik dihadapkan dengan simuasi yang merangsang peserta didik untuk mempelajari lebih lanjut materi pembelajaran, menyelidiki, membuat hipotesis, membuktikan dan membuat kesimpulan. Pada proses ini, guru berperan sebagai fasilitator yang memberikan kemudahan serta bimbingan sehingga peserta didik lebih memahami materi yang dipelajari. Sehingga berdasarkan hasil signifikansi yang diperoleh yaitu 0.000 adalah lebih kecil dari taraf signifikan yaitu 0.05 dandiperoleh hasil $\square \square \square$ sebesar 2.045 dan $\square_{h \square \square \square \square \square}$ sebesar 21.921 sehingga terbukti bahwa $\square_{h \square \square \square \square}>\square_{\square \square \square \square \square}$ yaitu $21.921>2.045$ ini berarti $H o$ ditolak dan $\square_{1}$ diterima. Artinya jika $\square_{l}$ diterima maka terdapat pengaruh yang signifikan terhadap kemampuan kognitif peserta didik yang menggunakan model pembelajaran Advance Organizer kelas 
XI SMK Kautsar Karang Pucung Lampung Selatan.

Salah satu faktor keberhasilan peningkatan kemampuan kognitif peserta didik yang lebih tinggi pada kelas eksperimen dibandingkan kelas kontrol adalah keterlaksanaan model pemelajaran advance organizer. Berdasarkan Tabel 4.10 persentase keterlaksanaan model pembelajaran advance organizer pada pertemuan pertama sebesar 90.5\% sehingga termasuk kategori sangat baik, pada pertemuan kedua sebesar 95.6\% termasuk kategori sangat baik. Dari kedua pertemuan, pertemuan kedua lebih tinggi dari pertemuan pertama. Hal tersebut karena pada pertemuan pertama peneliti masih belum mampu menguasai kelas dengan baik, sehingga peneliti belum mampu mengondisikan peserta didik dengan baik.

Berdasarkan persentase jumlah keseluruhan skor observer pada lembar observasi menunjukkan bahwa persentase rata-rata observasi keterlaksanaan model pembelajaran advance organizer sebesar $93.05 \%$. Sehingga dapat disimpulkan bahwa keterlaksanaan model pembelajaran advance organizer pada kelas eksperimen terlaksana dengan sangat baik.

\section{KESIMPULAN}

Berdasarkan hasil penelitian dan pembahasan pada bab IV, maka skripsi dengan judul "Pengaruh Model Pembelajaran Advance Organizer untuk Meningkatkan Kemampuan Kognitif Peserta Didik Pokok Bahasan Fluida Dinamis SMK" dapat disimpulkan sebagai berikut.

1. Terdapat pengaruh signifikan setelah penerapan model pembelajaran Advance Organizer terhadap peningkatan kemampuan kognitif peserta didik pokok bahasan Fluida Dinamis SMK. Hal tersebut ditunjukkan pada perhitungan uji-t yang menghasilkan $\square_{h \square \square \square \square \square}>$ dengan nilai $21.921>2.045$ yang berarti $\square_{0}$ ditolak dan $\square_{1}$ diterima.

2. Peningkatan kemampuan peserta didik dapat dilihat dari hasil belajar peserta didik pada. Pada kelas eksperimen pada tahap pertama diberikan tes kemampuan kognitif (pretest) sehingga didapatkan ratarata $=40.16$, setelah adanya perlakuan pemberian model pembelajaran advance organizer diberikan kembali posttest sehingga didapat hasil belajar meningkat menjadi $=81.94$.

\section{DAFTAR PUSTAKA}

Abdurrahman. (2017). Efektivitas dan Kendala Pembelajaran Sains Berbasis Inkuiri terhadap Capaian Dimensi Kognitif Siswa: Meta Analisis tantangannya dalam upaya. Jurnal Keguruan Dan Ilmu Tarbiyah, 2(1). https://doi.org/10.24042/tadris.v2il. 1206

Alamsyah, T. P., \& Turmudi. (2016). Kemampuan Berpikir Kritis Dan Kreatif Serta Self Esteem Matematis Siswa Melalui Model Advance Organizer. Jurnal Pendidikan Fisika, 1(2).

Ananto, H., \& Yuberti. (2018). Pengaruh Model Pembelajaran POE Terhadap Keterampilan Proses Belajar Fisika Pokok Bahasan Suhu Dan Kalor. Indonesian Journal of Science and Mathematics Education, 1(1).

Arikunto, S. (2013). Prosedur Penelitian Suatu Pendekatan Praktik. Jakarta: Rineka Cipta.

Asmawati, E. Y. S. (2015). Lembar Kerja Siswa (LKS) Menggunakan Model Guided Inquiry Untuk Meningkatkan Keterampilan Berfikir Kritis Dan Penguasaan Konsep Siswa. Jurnal Pendidikan Fisika, 3(1). 
Diani, R., Yuberti, \& Syafitri, S. (2016). Uji Effect Size Model Pembelajaran Scramble Dengan Media Video Terhadap Hasil Belajar Fisika Peserta Didik Kelas X MAN 1 Pesisir Barat. Jurnal Ilmiah Pendidikan Fisika AlBiRuNi, 5(2).

Jumiati, Martala, S., \& Dian, A. (2011). Peningkatan Hasil Belajar Siswa Dengan Menggunakan Model Numbers Heads Together (NHT) Pada Materi Gerak Tumbukan Di Kelas VIII SMP Sei Putih Kampar. Lectura, 2(2).

Mustari, M. (2015). Pengaruh Penggunaan Media Gambar Lewat Komputer Terhadap Hasil Belajar Fisika Pada Siswa Kelas X SMA Negeri 3 Makasar. Jurnal Pendidikan Fisika Al-Biruni, 4(2).

Mustari, M. (2016). Pengembangan Instrumen Ranah Kognitif Pada Pokok Bahasan Fluida Statis SMA/MA. Jurnal Pendidikan Fisika Al-Biruni, 5(1).

Namira, Z. B., Kusumo, E., \& Prasetya, T. (2014). Keefektifan Strategi Metakognitif Berbantu Advance Organizer Untuk Meningkatkan Hasil Belajar Kimia Siswa. Inovasi Pendidikan Kimia, 8(1).

Nugroho, S. E. (2014). Pengaruh Advance Organizer Berbasis Proyek Terhadap Kemampuan Analisis-Sintesis Siswa. Jurnal Pendidikan Fisika Indonesia, 10(2).

Nugroho, T. S. ., \& Hartono. (2014). Analisis Tingkat Motivasi Siswa Dalam Pembelajaran IPA Model Advance Organizer Berbasis Proyek. Pendidikan IPA Indonesia, 3(1).

Selly, A., Diana, N., \& Yuberti. (2018). Analisis Miskonsepsi Siswa SMP Pada Materi Fisika. Journal of Science and Mathematics Education, 1(2).
Sinulingga, K., \& Munte, D. (2012). Pengaruh Model Pembelajaran Advance Organizer Berbasis Mind Map Terhadap Hasil Belajar Fisika Siswa Pada Materi Pokok Besaran Dan Satuan Di Kelas X SMA. Jurnal Pendidikan Fisika, 1(2).

Sudijono, A. (2015). Pengantar Statistik Pendididkan. Depok: Raja Grafindo Persada.

Sugiyono. (2011). Metode Penelitian Pendidikan Pendekatan Kuantitatif, Kualitatif dan $R \& D$. Bandung: Alfabeta.

Sungkawan, R. (2013). Analisis Penguasaan Konsep Awal Fisika Pada Pembelajaran Menggunakan Model Advance Organizer Berbasis Eksperimen Terhadap Hasil Belajar Fisika. Pendidikan Fisika, 2(2).

Widiyatmoko, A. (2012). Pengembangan Perangkat Pembelajaran IPA Fisika Dengan Pendekatan Physics-Edutainment Berbantuan $\mathrm{Cd}$ Pembelajaran Interaktif. Journal of Primary Education, 1(1). 